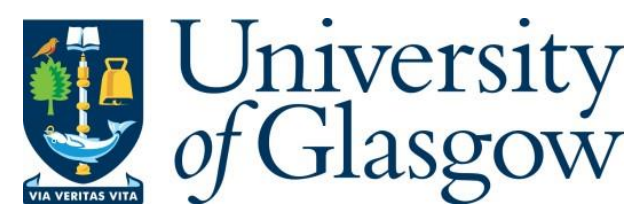

Liñeira, R. (2016) Second-order elections: everyone, everywhere? Regional and national considerations in regional voting. Publius: The Journal of Federalism, 46(4), pp. 510538.

There may be differences between this version and the published version. You are advised to consult the publisher's version if you wish to cite from it.

$\underline{\text { http://eprints.gla.ac.uk/219966/ }}$

Deposited on: 15 July 2020

Enlighten - Research publications by members of the University of Glasgow http://eprints.gla.ac.uk 


\title{
Second-order Elections: Everyone, Everywhere? Regional and National Considerations in Regional Voting
}

\author{
Robert Liñeira \\ University of Edinburgh \\ robert.lineira@ed.ac.uk
}

\begin{abstract}
:
Vote choice in regional elections is commonly explained as dependent on national politics and occasionally as an autonomous decision driven by region-specific factors. However, few arguments and little evidence have been provided regarding the determinants that drive voters' choices to one end or the other of this dependency-autonomy continuum. In this article we claim that contextual and individual factors help to raise (or lower) the voters' awareness of their regional government, affecting the scale of considerations (national or regional) they use to cast their votes at regional elections. Using survey data from regional elections in Spain, we find that voters' decisions are more autonomous from national politics among the more politically sophisticated voters, among those who have stronger feelings of attachment to their region, and in those contexts in which the regional incumbent party is different from the national one.
\end{abstract}


In their landmark article Reif and Schmitt (1980) drew a distinction between first and secondorder elections. According to their definition, countries have only one 'important' election whereas there is 'less at stake' in all others. The main difference between these two types of votes is electoral participation, with turnout being systematically higher in first-order votes. This fact is taken as a signal that citizens have less interest in and knowledge about the politics of the less mobilizing second-order elections. As a result, voters need to use considerations derived from the first-order arena to make up their minds in any second-order vote. ${ }^{1}$

Unlike this top-down predominant view, other explanations have emphasized the autonomy of vote choice in elections to non-national offices. The opposite perspective states that the citizens' vote and the outcome are hugely influenced by the actors involved in the specific electoral levels; factors such as the candidates and the governments, with their respective campaign strategies and performance, have a crucial effect on voters' choices. These explanations, which emphasize the autonomous nature of voting patterns at different types of elections, have been used to account for split-ticket voting in the US (Jacobson 1991) or regional election outcomes in contexts such as provincial elections in Canada or devolved elections in the UK (Cutler 2008; Johns et al. 2009).

The autonomous nature of less mobilizing elections has also been accounted for by the notion that elections to different institutions are about different issues, i.e., voters focus on distinct policy-areas depending on the office to be elected. In contrast to the second-order view, it is not a question of 'how much is at stake' but rather of 'what is at stake'. This interpretation has been used to explain congressional (Petrocik and Doherty 1996; Shafer and Claggett 1995) and 
gubernatorial elections in the US (Atkeson and Partin 1995; Stein 1990), or even European Parliament elections (Curtice and Steed 2000). ${ }^{2}$ At regional elections, the argument has been mainly used in multinational contexts where the party systems operating at the sub-state and the state tiers differ (Curtice 2001; Denver and Johns 2010; Jones and Scully 2006; Liñeira 2011).

Although the distinction between first- and second-order has been the dominant framework in the non-national elections literature, some authors have questioned its simplicity. First, the straightforward dichotomy between the national level and 'everything else' has been considered inadequate (Jeffery and Hough 2003). Instead, elections could be better interpreted within a continuum which ranges from purely autonomous elections - with decisions driven entirely by factors pertaining to that arena - to purely dependent ones on the national arena (van der Eijk and Franklin 1996). Second, it has been stated that not all voters approach a given election in the same way. Johns (2011) argues that within second-order elections there is variation depending on institutions, contexts, and individuals. Institutionally, the level of dependency may vary across countries, regions or time because what is at stake may differ according to the powers granted to the different sub-state units. Contextually, dependency may vary depending on the parties in government or as a result of an economic crisis. Individually, different voters may perceive the importance of each electoral arena differently.

The question of whether regional elections are dependent on or autonomous from national politics is of more than academic interest. A necessary condition for regional democracy is some degree of electoral accountability that helps to establish responsible and representative regional governments. If regional elections are disconnected from regional politics, voting patterns will 
lack meaning, significance or relevance for the regional political process. This democratic deficit would be especially worrisome since regional institutions have increased their powers and responsibilities over the last decades in contemporary democracies (Hooghe, Marks, and Schakel 2010; Rodden 2004). Devolving powers to institutions with unaccountable and unresponsive governments would mean that voters lose both control over policymakers and influence on policies. As a result, it is crucial to evaluate the drivers of regional elections and the factors that moderate the importance of regional and national considerations on ballot choice.

In this article, we focus on retrospective evaluations to assess the scale of considerations that drive voters' choices in regional elections; the question of electoral accountability seems particularly appropriate in assessing the drivers of regional vote choice because the main consequence of multilevel settings is to blur the clarity of responsibilities. ${ }^{3}$ This interest forces us to use individual-data analysis in order to introduce voters' attitudes and evaluations into the analysis and assess the weight voters give to regional and national considerations when they choose their ballots. ${ }^{4}$ Despite our use of survey data, we also take benefit of the Spanish context to use a comparative strategy that examines the moderating role that different political contexts have on the effect of regional and national politics on regional voting. The Spanish regional elections then constitute a crucial test given the variation in Spanish regional politics - 17 regions with similar institutions but different party systems - and the richness of the available data.

Our main argument is that voters' awareness of the regional government makes regional politics more relevant to vote choice in regional elections. This awareness is a variable that depends on 
both contextual and individual factors; politically sophisticated voters, those who identify more strongly with the regions, and those living in regions governed by a different party than the national incumbent are more aware of the regional government and give more weight to regional retrospective evaluations when making their regional vote choices. By contrast, unsophisticated voters, those who identify more strongly with the nation, and those located in regions governed by the national incumbent are less aware of the regional government and, as a result, give more leverage to considerations derived from the national politics when casting their regional ballots.

The article is structured as follows. In the next section, we present the main theoretical arguments and the hypotheses. The following section discusses the relevance of the Spanish regional elections to test our hypotheses and presents the model we use to test them as well as the operationalization and the data used. The results are shown in another section; the moderating roles of political sophistication, national identity and incumbency status will be presented in different sub-sections. The final section summarizes the findings and discusses their relevance for the literature on regional voting.

\section{Theoretical Arguments}

Electoral accountability requires clarity of responsibilities. In order to hold governments to account, voters must have a clear picture of the government and the party responsible for past policy outcomes. Under such premises, successes will be rewarded and failures will be punished on the basis of past performance at subsequent elections (Anderson 1995; Manin, Przeworski, and Stokes 1999; Powell 2000; Powell and Whitten 1993; Rudolph 2003b). Logically, the nature 
of institutions and governments has an effect on the clarity of responsibilities; in contrast to situations of unified power, it is more difficult for voters to identify who is responsible when power is divided. Therefore, decentralized polities make it more difficult for voters to pinpoint responsibilities than do unitary polities (Alesina and Rosenthal 1996; Anderson 2006; Cutler 2004; Powell and Whitten 1993; Remmer and Gélineau 2003; Rudolph 2003a).

Yet, institutions are not the whole story. The effect of multilevel governments on the clarity of responsibilities might be moderated by the parties in office at each tier of government.

Obviously, identifying who is responsible is easier in regions with the same incumbent party at both levels. This has led to the argument that voters cannot do wrong in holding this party responsible for any outcome, so in-party governments are more accountable than out-party governments (Lago-Peñas and Lago-Peñas 2010). ${ }^{5}$

However, the latter conception of accountability overlooks the responsibilities by the different governments; i.e., to attribute all responsibilities to the party without making any distinction between the performance of the national and the regional government would lead voters to blame or reward incumbents for actions which fall under the responsibility of another administration. This would harm accountability. Additionally, the 'restricted in-party culpability thesis' (Hibbing and Alford 1981) suggests that the effect of national conditions on the vote is largely confined to elections involving in-party incumbents (see also Atkeson and Partin 1995; Fiorina 1983; Koch 2000; Stein 1990). For all this, we expect that national politics would have a greater effect on regional elections in the context of in-party governments, leading to less accountable regional governments. 
In detail, our argument is as follows. The common party label of in-party governments raises the saliency of the national office over the regional one because the former is run by the main leaders of the party. Under these circumstances, it is more challenging for the voter to have a genuine and distinctive evaluation of the regional government's performance, so voters are impelled to give more leverage to national considerations when casting their regional ballots. By contrast, voters can more easily relate the policies carried out by the different governments when different parties hold the regional and the national office, a situation which has been labeled as 'divided federalism' (Brown 2010). Therefore, out-party contexts should increase the voters' awareness of the regional government and facilitate more genuine and consequential performance evaluations.

In summary, the more distinctive the regional is from the national government, the easier for the electorate to discriminate between the policy actions of the different governments, and the greater the impact of regional considerations on regional voting. Thus, our first hypothesis is:

H1.Regional considerations will be more important vis-à-vis national considerations when voting for the regional government in out-party governments than in in-party governments

Apart from variances across regions, the kind of considerations that voters use to cast their ballots may also vary among individuals. Multilevel government settings make it less clear who is responsible for what, which may force citizens to acquire additional information to correctly 
assign responsibilities (Anderson 2006, 450, 2008, 330; Cutler 2004, 19-22; Hobolt and Tilley 2014, 29-48). Political sophistication then emerges as a potential source of variation on how voters make up their minds in regional elections.

Decades of research on public opinion have shown the electorate's ignorance about basic political facts (Delli Carpini and Keeter 1996; Fournier 2002; Neuman 1986). Political knowledge, however, is not just characterized by a low mean, but also by a high variance, i.e., the levels of awareness vary a great deal among citizens (Converse 1975). These differences in voters' levels of political conceptualization and awareness have as many consequences as do their differences in values and interests (Converse 1964; Zaller 1992): the politically aware are more competent in processing news and information, in converting this into stored knowledge (Zaller 1991), and in perceiving objective facts (Bartels 2002). These differences translate into voting behavior (Bartels 1996; Duch, Palmer, and Anderson 2000).

As the existence of different tiers of government add complexity, we might expect that decentralized polities accentuate the consequences of voters' political knowledge on voting. On the one hand, evidence exists that political awareness and knowledge have some impact on the attributions of responsibility to the different tiers of government in Canada, the UK, and Spain (Cutler 2008; Johns 2011; León 2011; Liñeira 2014). There is also evidence that sophisticated voters are more interested in regional politics and are more cognizant of the regional leaders (Liñeira 2014, 127-175). If considerations relative to regional politics are more accessible to sophisticated voters, and less so to unsophisticated ones, the former will tend to make more use of them than the latter to cast their ballots. Thus, our second hypothesis is: 
H2.Regional considerations will be more important vis-à-vis national considerations when voting for the regional government among sophisticated voters than among unsophisticated voters.

Political sophistication and awareness may not be the only source of difference on how voters make their choices. In multinational polities, voters' sense of belonging may affect their locus of political interest; voters with a strong sense of regional identification are more interested and informed about regional politics (Liñeira 2014, 127-175), and seem likely to view regional elections as more important than those who feel less identified (Johns 2011). The effect of national identity on the awareness of regional elections may also result from different perceptions of how responsibility is allocated across levels; the attribution of responsibilities is not just biased by ideological and partisan predispositions (Arceneaux 2006; Rudolph 2003a, 2003b, 2006; Tilley and Hobolt 2011), but also by voters' identity and their predisposition to attribute powers to the levels of government with which they identify more (Johns 2011). Therefore, it is reasonable to expect that those who more strongly identify with their region give more weight to regional considerations at regional elections.

H3. Regional considerations will be more important vis-à-vis national considerations when voting for the regional government among voters who feel more strongly attached to their region than among those who feel less attached to it. 


\section{Method and Data}

Regional elections in Spain constitute a key test of the previous hypotheses given their homogeneous institutional setting and their heterogeneity in terms of election timing and party systems. This allows us to take advantage of the subnational comparative method: by focusing on subnational cases within a single country we control for institutional heterogeneity - i.e., the government and the electoral systems, or the characteristics of the central government - to a far greater extent than is usually possible in studies that compare units within different federations (Snyder 2001).

The process of decentralization in Spain established seventeen regions with their own democratically elected institutions. Four of these regions were granted the maximum-level of self-government allowed by the Spanish constitution at the outset (the so-called fast-track regions), whereas the other thirteen had to wait for five years before being able to increase their powers. Yet, the evolution of the decentralization process has equalized the responsibilities attributed to these two type of regions, to such an extent, that few differences exist in terms of

policy responsibilities across regions (Aja 2003). ${ }^{6}$ Additionally, even though each region could originally choose its own institutional setting, all eventually replicated the basics of the Spanish government system: a parliamentary regime elected by proportional representation with fouryear terms.

Electoral timing is the main institutional difference. The thirteen slow-track regions hold their elections on the same day every four years, whereas the fast-track regions have the power to dissolve their parliaments and hold their elections separately from any other vote. Concurrent 
regional elections may boost the relevance of national factors in the elections of the slow-track regions because the national media are encouraged to cover the campaigns and the national parties are prompted to co-ordinate their messages and emphasize national issues (Colomer 1998; Golder 2006). ${ }^{7}$ By contrast, non-concurrent elections provide greater opportunities for maintaining a distinctive agenda, which may weak the influence of national issues on regional voting.

Yet, it is the party systems rather than the institutions that form the main source of differences. Although the main Spanish state-wide parties, the Popular Party (PP) and the Socialist Party (PSOE), are present in all regions, they co-exist with a plethora of non-state-wide parties (NSWPs). ${ }^{8}$ This diversity is set out in Table 1 which shows the outcomes of the regional elections held between 2008 and 2011 by region. Particular regard should be paid to the last two columns which show the support to the two main state-wide parties and the votes gathered by all the NSWPs respectively. The PSOE and the PP garner more than the 90 per cent of the votes in Castille-La Mancha or Extremadura whereas they receive under 50 per cent in Catalonia, Navarre, or the Basque Country where, instead, NSWPs accrue a majority of votes. Within these two types of party landscapes, we find different party subsystems with a greater or lesser number of regional specificities. ${ }^{9}$

[Table 1 here]

Spanish regional elections then constitute a key environment in which to assess our hypotheses. However, in order to evaluate how the drivers of regional elections vary across contexts and 
between voters, we first need a method to estimate the relative weight given to national and regional considerations on vote choices. We may follow two strategies. First we may ask the voters themselves. However, even if voters' answers to these kinds of questions is not without value, we will question in the next section the validity of this strategy in assessing voters' motivations. Alternatively, we may contrast the impact of regional and national considerations on the vote through regression models. We will focus on this second strategy. Adding interaction terms to these regressions models we will be able to assess how the impact of different considerations varies across contexts and among different types of voters, which is the main concern of this article.

As said, we will use retrospective models to assess the role of national and regional considerations on the vote. Thus, our dependent variable is a dummy which contrasts those who voted for the regional government party (or parties in the case of coalition governments) with those who supported the opposition parties. ${ }^{10}$ The main predictors are the voters' performance evaluations of the regional and national political actors, particularly, the governments and the leaders. Therefore, the model evaluates the impact of regional retrospective evaluations on the decision to support the regional government or the regional opposition, once we take into account the retrospective evaluations of the national government and the national prime minister.

To this basic model we add some controls. First, we include voters' attitudes towards the incumbent regional party by incorporating two measures: the voters' sense of proximity to and ideological distance from the party of the regional president. Controlling for partisan and ideological attitudes is necessary for several reasons. On the one hand, we know that partisanship colors perceptions and evaluations (Bartels 2002; Evans and Pickup 2010), so we need to introduce 
political predispositions into the analysis to make sure that our retrospective evaluations are genuine and not just a by-product of predispositions. Also, these predispositions help us to mitigate the potential endogenous relationship between evaluations and vote choice by introducing factors that are both related to the evaluations and the vote (Anderson, Mendes, and Tverdova 2004; Bartels 2002; Duch, Palmer, and Anderson 2000; Evans and Andersen 2006; Evans and Pickup 2010; Wlezien, Franklin, and Twiggs 1997; but see Lewis-Beck 2006; Rudolph 2003b, 2006). ${ }^{11}$ Finally, given that the chances of supporting the government may depend on the credibility of the opposition (Anderson 2000; Sanders and Carey 2002), we include a measure of the regional opposition performance. ${ }^{12}$

Thus, the independent variables used in this and subsequent models are the voters' retrospective evaluations of the regional and national government, measured with a five-point scale which ranges from 'very good' to 'very bad'; the voters' proximity to the party of the regional president, varying from 'very close' to 'not close at all'; the voters' ideological distance from the same party on the left-right spectrum; ${ }^{13}$ and the voters' ratings of the regional president and of the Spanish prime minister measured in a 0 to 10 scale. All the variables have been recoded to range from 0 to 1 in order to compare the magnitude of the coefficients. Finally, we must underline that all the models use clustered standard errors to take the hierarchical structure of the data into account.

The data are drawn from the pool of the seventeen post-electoral surveys conducted after the regional elections held between 2008 and 2011; respondents were interviewed face-to-face in representative samples in each Spanish region, with sample sizes ranging from 580 respondents in Navarra, to 2,500 in Catalonia. ${ }^{14}$ These elections were held during the second term of the socialist prime minister José Luis Rodríguez Zapatero's, a period characterized by a huge economic crisis 
which caused increasing levels of unemployment that saw the image of the national socialist government to deteriorate rapidly. ${ }^{15}$

\section{Results}

The following question was asked in the post-election surveys of the thirteen slow-track regions: 'when you reached your decision about your vote (or your non-vote) in past regional elections, what did you take more into account: regional issues or Spanish issues?' Table 2 displays the answers by region. They depict a pattern in which Spanish regional elections appear to be quite autonomous from national considerations: a mean of 52 per cent of the respondents state that they focused on regional issues at regional elections, 19 per cent say they concentrated on Spanish issues, and 24 per cent chose the 'both' category. Although there are substantial variations across regions, it is only in the region of Madrid that more respondents claimed to be more influenced by national rather than by regional issues.

[Table 2 here]

Although the data displayed on Table 2 provide a valid picture of the dominant logic used to justify vote choices across regions, its validity as a measure of what drives the vote at regional elections is open to question. There is compelling evidence that asking voters for the reasons of their choices does not reveal the 'real' ingredients of those decisions but, rather, their subsequent rationalizations (Rahn, Krosnick, and Breuning 1994). Furthermore, when asked to explain their preferences and behavior, people are biased toward mentioning reasons that sound rational and 
that emphasize the object being evaluated (Wilson et al. 1989), and 'regional issues at regional elections' might sound like a rational answer. It also may sound as sophisticated answer, so some voters might choose it because it seems appropriate to state that their regional vote choices are driven by regional concerns, incurring in a social desirability bias. For all these reasons, we need a different strategy to estimate the relative impact of regional and national considerations on vote choice.

A regression estimation provides a more robust evidence about the kind of considerations that drive the regional vote. Table 3 shows 5 models that estimate the effect of our independent variables on the support for the regional government. The first model includes the voters' predispositions towards the incumbent party in the region; the second adds the voters' assessments of the regional and the national government's performance; model 3 uses the evaluations of the regional president and the Spanish prime minister; model 4 includes all the retrospective evaluations of the national and regional incumbents, and model 5 adds the evaluation of the regional opposition leader to the previous independent variables. Finally, we introduce a dummy that separates the PSOE regional governments from the other regional governments, plus an interaction between the dummy and the evaluations of the national objects. This interaction allows us to adequately model the opposite effect that the evaluations of the PSOE national government has on the support for the regional government: positive in the case of PSOE regional governments, and negative in those regions where the PSOE belongs to the opposition. 
The models displayed in Table 3 show that all variables work in the expected direction. Model 1 (and all subsequent models) shows that the closer the voter feels to the regionally incumbent party, or the shorter the ideological distance, the more likely it is that he or she voted for it. In model 2 we appreciate that the impact of the prime minister's evaluation is negative $(-2.082)$ in out-party governments, but positive in the context of in-party governments $(3.378-2.082=$ 1.296). The same pattern is evident in model 3, which replaces governments with leaders: the impact of the regional president evaluation (3.251) is positive and greater than the impact of the national prime minister (-2.522). Finally, models 4 and 5, which take into account all the relevant considerations, make evident that the impact of regional considerations tends to be greater than the impact of the national ones. Although the evaluations of the national government and prime minister are not irrelevant, their impact is smaller than the retrospective evaluations of their regional counterparts.

[Table 3 here]

\section{Divided and United federalism}

In a decentralized polity it is more difficult for voters to know which government is responsible for a given outcome (Alesina and Rosenthal 1996; Anderson 1995, 2006; Cutler 2004). However, the effect of federations on electoral accountability might be moderated by the parties in office at each tier of government. Specifically, we expect that contexts with different incumbent parties at each level of government make voters more aware of their regional government and, in consequence, more able to keep a distinctive, genuine, and consequential 
evaluation of its performance. By contrast, maintaining a specific evaluation of the regional government's performance in the context of in-party governments should be more demanding, so voters will rely more on national considerations to cast their ballots.

Table 4 displays two models that test the impact of regional and national evaluations on the vote in out-party and in-party governments; in order to not overstate the effect of regional considerations, the analysis considers only regions governed by either the PP or the PSOE and excludes regions governed by NSWPs. ${ }^{16}$ The first model contrasts the impact of the regional government's evaluations in different contexts: in those regions governed by the PP, the coefficient (4.183) is larger than in those regions governed by the PSOE $(4.183-1.175=3.008)$. Therefore, we may conclude that the evaluations of the regional government have a stronger impact on the vote in contexts of divided federalism, i.e., the PSOE is the national incumbent and the PP is the regional one.

[Table 4 here]

However, the previous model does not constitute a complete fair test of our hypothesis; the evaluations of the national government are evaluations of a PSOE government, so it should not surprise that they exert a stronger impact on the support of regional governments in which the PSOE is the incumbent. In order to compare like with like model 2 focuses on leaders, which constitute the only object that distinguishes the regional from the national politics in regions with a PSOE incumbent. Again, we presume that national politics would exert a stronger influence on the regional vote in the context of in-party governments, so regional presidents from the PSOE 
should influence less the vote than regional presidents from the PP once we control for the evaluations of the national prime minister and the national opposition leader. Model 2 and Figure 1 make evident that differences occur in the expected way; in the context of in-party governments, the dominance of national politics makes regional evaluations less relevant for the vote choice than in regions where incumbents belong to different parties.

[Figure 1 here]

\section{Individual variations}

The previous models did not make any distinctions among voters, but individuals do not necessarily share a process of voting decision (Bartle 2005; Rivers 1988; Sniderman, Brody, and Tetlock 1991). On the contrary, it is reasonable to expect that choices made by different voters are driven by a wide range of interests, motivations, and abilities. If we relax the homogeneity assumption, we must accept the possibility that voters weigh the various considerations differently when casting their regional ballots. We should, therefore, expect that the impact of regional and national considerations on voting varies depending on the characteristics of the different voters. Given that previous evidence shows that the level of involvement with regional politics is conditioned by citizens' national identity and political sophistication (Johns et al. 2009; Liñeira 2014), we will test in this section if these two factors modify the ingredients used by voters to make their regional election choices. 
The conditional effect of national identity

Identity and the promotion of the region's interests are specially salient issues in regional elections (Curtice 2001; Johns 2011). ${ }^{17}$ Furthermore, evidence shows that the stronger the individual's feeling of identification with the region, the higher their interest in and knowledge of the region's politics (Liñeira 2014). Therefore, we expect that regional politics exert a more decisive impact on the vote choice of those individuals who have a strong identification with the region.

Table 5 shows two models to test this. The first column of model 1 shows the effects of the different explanatory factors on the vote of those who mainly identify with Spain ('only Spanish' and 'more Spanish than from the region'), whereas the second column focuses on those who feel more strongly attached to their region. As a first test, respondents who feel equally attached to Spain and to their region are excluded from model 1. They will be included in model 2.

The results show similar coefficients on the impact of regional government assessment for both groups. However, the impact differs strongly when it comes to evaluation of the national government's performance: this is a significant explanatory factor for those who feel more strongly attached to Spain, but a non-significant one for those who feel more attached to their region. Model 2 tests if the latter difference is statistically significant. Given that the impact of national identity could be different in those regions which held their elections separately (thereby allowing more opportunities to introduce regional issues into the election campaign), the model 2 distinguishes between the impact of our interest variables in all regions and in slow-track regions. The effects can easily be seen in Figure 2. 
[Table 5 here]

Both figures clearly show that a conditional relationship exists between national identity and the kind of considerations used at the ballot box: the greater the attachment to the region, the lesser the impact of national political considerations on regional voting and vice versa. Consequently, those more strongly attached to Spain take the performance of the national government more into account when casting their regional ballots than those with a stronger feeling of attachment to their region. Obviously, the direction of this effect changes according to the regional incumbent: if the incumbent is the PSOE, a good evaluation of the socialist national government has a positive effect on support for the PSOE at the regional level, whereas if the regional incumbent has a different party label (and the PSOE is an opposition party), the impact of the national government on the regional incumbent's re-election is negative. Finally, the panel on the right of the figure shows that these effects also exist in the slow-track regions, so we can exclude the possibility that national identity only makes a difference in regions in which a national cleavage divides the party system, as is the case in Catalonia and the Basque Country. On the contrary, it appears that voters' identity moderates the role played by national politics in voting across all Spanish regions.

[Figure 2 here] 
The conditional effect of political sophistication

Public opinion research has emphasized that politically sophisticated citizens engage differently with politics than do the politically unsophisticated (Converse 1964; Duch and Palmer 2002; Duch, Palmer, and Anderson 2000; Zaller 1992). Political sophistication is a multidimensional concept. According to Luskin, 'a person is politically sophisticated to the extent to which his or her political cognitions are numerous, cut a wide substantive swath, and are highly organized, or constrained' (Luskin 1990, 332). Together with measures of political knowledge (unavailable in our data), education is the most common measure of political sophistication.

A large body of research shows that educational attainment promotes abstract reasoning abilities among individuals who engage in more complex approaches to political information (Luskin 1990) and more demanding decision-making strategies in cognitive terms (Delli Carpini and Keeter 1996, 110-111). Education also provides individuals with the ability to learn about politics by teaching them cognitive skills and political facts (Delli Carpini and Keeter 1996, 110), at the same time it increases the scope of political reasoning and 'the number of issues that citizens see as politically relevant' (Popkin 1994, 36). Finally, the more educated are also more likely to be interested in the political world (Delli Carpini and Keeter 1996, 179) and motivated to gather political information (Delli Carpini and Keeter 1996, 110-111). In summary, education is related to greater motivation to gather political information and more sophisticated skills to process it. Therefore, we expect that the politically sophisticated are better equipped to understand a multi-level government structure and to use national or regional considerations depending on the electoral level. 
Table 6 displays the results of the interaction between governments' evaluations and education. In order to extend the evidence, we have estimated the same model using the evaluations of the regional president and the evaluations of the Spanish prime minister as interaction terms. Both governments and presidents' performance ratings show that national political considerations have a weaker impact on the regional choices of the more educated. According to our evidence, voters with higher educational attainment give more leverage to regional evaluations in their vote decisions than do individuals with lower levels of education. Additionally, the leaders' evaluations show a similar pattern: performance ratings for the Spanish prime minister have a weaker impact on the voting decisions of the highly educated.

[Table 6 here]

Figure 3 helps us grasp the effects of education more readily. The top two panels show that the higher the educational attainment, the higher the impact of regional's evaluations on vote choice. Similarly, the bottom panels show that national considerations have a decreasing effect on voting as formal education increases. In fact, education shows no effect among those with secondary and tertiary education. In short, academic education reveals the expected effect in the expected direction, showing that educational attainment moderates the focus of voters' considerations.

[Figure 3 here]

\section{Summary and Discussion}


Regional voting is usually explained as being dependent on the dynamics of national politics, and occasionally as an autonomous decision driven by region-specific influences. We contributed to this debate by providing arguments and evidence as to the determinants that drive voters' choices to one end or the other of this dependency-autonomy continuum. The data used are drawn from surveys of regional elections in Spain because they constitute a critical test: the institutional set-up of the different regions is similar, which allows us to control for the institutional and political differences inherent in any cross-country regional comparison.

Even if it is not always easy for the public to separate issues of national and regional politics, our analysis shows that regional considerations appear as a greater determinant of ballot choices than national ones; i.e., the voters' regional evaluations of governments and leaders have a stronger effect on their regional vote choices than do national ones. On the continuum of regional voting being either a decision that is purely autonomous from national politics or purely dependent, Spanish regional elections appear to be closer to the autonomy end of that scale than to the dependency end when we examine on the considerations in the minds of voters.

However, our most relevant finding is related to moderation effects. The more visible a regional government becomes vis-à-vis the national government, the more relevant regional considerations are to regional vote choice. Contextual and individual factors help to make voters more aware of the regional government. On the one hand, we have found support for our hypothesis that different party incumbents at the regional and national levels result in regional considerations gaining leverage on voters' decisions. On the other hand, evidence shows that, when the incumbent party is the same, regional considerations fade in the voters' minds at the 
expense of national ones. Although we test this in the context of the Spanish regional elections, we find no reasons to expect a different pattern in further research in other multilevel settings.

Voters' own characteristics also have a conditional effect on the relative importance of regional and national considerations on their vote. First, we have found that voters with higher educational attainment and, therefore, higher capacity to process political information in a complex institutional setting are more sensitive to regional politics at the polls than voters with lower educational attainment. Second, the centrality of regional identity issues in Spanish regional politics becomes evident: it impacts on constitutional preferences, as well as involvement with and knowledge of regional politics. It also affects the tier of government voters take into account when making their regional vote choices.

In summary, the moderating role of education and national identity shows that voters do not share a common decision-making process in terms of voting in a complex institutional setting such as the Spanish state of the autonomies. These findings should also hold in other multilevel settings, i.e., sophisticated voters should be more aware of any level of government and use the specific-level considerations for making their vote choices. In the same way, we should find that national identity shows similar effects other multinational polities with regional and national elections such as the United Kingdom or Canada. Future research should establish if these findings also hold in other contexts.

Does decentralization harm citizens' capacity to hold governments to account? Few doubts exist that the existence of different tiers of government raises the question about who is responsible, 
making things more difficult for voters. However, attributions of responsibility do not matter as much to voters at the ballot box as heuristics and general impressions. According to our analysis, voters take into account how well the regional government and leaders did over the previous four years when casting their regional ballots. Consequently, even if it is true that regional elections are not only about the region and that electoral accountability is a difficult task in a multilevel context, the portrait of an electoral arena principally driven by considerations relating to national politics and failing, as a result, to hold regional administrations accountable appears to be more wrong than right.

The idea of regional elections as simple second-order votes is also too simplistic because the consequences of the institutional design depend on the political context and on voters' motivation. As in other forms of institutionally separated power (like presidential or semipresidential regimes) power is overtly dispersed when the different levels of government are controlled by different parties. In these contexts, it is easier for voters to maintain and use separate evaluations at the regional elections; i.e., power appears more divided in the eye of the voter when the vertical division of power and different party incumbencies coincide, uncoupling regional elections from national politics. Additionally, voters' motivations also moderate the scale of considerations: more educated voters and those who strongly identify with the region (in a multinational context) are more motivated to collect and process relevant information and, therefore, to give greater saliency to regional considerations when casting their ballots. 
Table 1 Electoral results in the 2008-2011 regional elections (\% valid vote)

\begin{tabular}{lrrrrrrr|rr}
\hline & PP & PSOE & IU & UPyD & NSWP-1 $^{1}$ & NSWP-2 & NSWP-3 & PSOE & Total \\
+ PP & NSWPs \\
\hline C. Mancha & 48.9 & 44.1 & 3.8 & 1.8 & & & & 93.0 & 0.3 \\
Extremadura & 46.8 & 44.1 & 5.8 & 1.1 & & & & 90.9 & 1.2 \\
Andalusia & 38.9 & 48.9 & 7.1 & & 2.8 & & & 87.8 & 3.4 \\
Rioja & 53.4 & 31.2 & 3.8 & 3.7 & 5.6 & & & 84.6 & 5.6 \\
Murcia & 60.1 & 24.4 & 12.7 & 4.6 & & & & 84.5 & 0.1 \\
C. Leon & 53.3 & 30.7 & 5.0 & 3.4 & 1.9 & & & 84.2 & 5.2 \\
Madrid & 53.0 & 26.9 & 9.9 & 6.5 & & & & 79.9 & 0.2 \\
Valencian Com. & 50.7 & 28.8 & 6.1 & 2.6 & 7.4 & & & 79.5 & 8.4 \\
Galicia & 47.5 & 31.5 & 1.0 & 1.4 & 16.8 & 1.1 & & 79.0 & 17.7 \\
Balearic Islands & 47.8 & 26.5 & 2.8 & 2.1 & 8.9 & & & 74.3 & 16.4 \\
Aragon & 41.0 & 30.0 & 6.4 & 2.4 & 9.5 & 8.5 & & 71.0 & 18.9 \\
Cantabria & 47.1 & 16.7 & 3.4 & 1.8 & 29.8 & & & 63.8 & 29.8 \\
Canary Islands & 32.9 & 21.6 & & 1.0 & 25.7 & 9.3 & & 54.5 & 37.6 \\
Asturias & 20.5 & 30.7 & 10.6 & 2.5 & 30.5 & 1.1 & 1.1 & 51.2 & 33.4 \\
Basque Country & 14.1 & 30.7 & 3.5 & 2.2 & 38.6 & 6.0 & 3.7 & 44.8 & 48.3 \\
Catalonia & 12.7 & 18.9 & 7.6 & & 39.6 & 7.2 & 3.5 & 31.6 & 51.5 \\
Navarre & 7.5 & 16.3 & 5.6 & & 35.4 & 15.8 & 13.6 & 23.8 & 68.0 \\
\hline
\end{tabular}

Source: Official data

\footnotetext{
${ }^{1}$ From top to down: Andalusian Coalition; Riojan Party; Leonese People's Union; Compromise; Galician Nationalist Bloc; Socialist Party of Majorca; Aragonese Party; Regionalist Party of Cantabria; Canarian Coalition; Asturias Forum; Basque Nationalist Party; Convergence and Union; Navarrese People's Union.

${ }^{2}$ From top to down: Galician Land; Aragonese Union; New Canarias; Independents of Asturias; Aralar; Republican Left of Catalonia; Navarre Yes.

${ }^{3}$ From top to down: Asturian Bloc; Basque Solidarity; Citizens; Bildu.
} 
Table 2 More relevant scale of issues in regional elections, by region (row percentage)

\begin{tabular}{lcccccc}
\hline & $\begin{array}{c}\text { Regional } \\
\text { issues }\end{array}$ & $\begin{array}{c}\text { Spanish } \\
\text { issues }\end{array}$ & Both & None & $\begin{array}{c}\text { Non } \\
\text { answer }\end{array}$ & n \\
\hline Navarra & 67 & 8 & 19 & 3 & 3 & 580 \\
Asturias & 65 & 5 & 27 & 0 & 3 & 573 \\
Canarias & 64 & 14 & 19 & 2 & 1 & 795 \\
Baleares & 60 & 20 & 16 & 3 & 3 & 922 \\
Aragón & 57 & 18 & 19 & 2 & 5 & 700 \\
Murcia & 56 & 13 & 27 & 2 & 3 & 989 \\
\hline Mean & 52 & 19 & 24 & 2 & 3 & - \\
Cantabria & 51 & 13 & 27 & 5 & 4 & 996 \\
Valencian Community & 50 & 23 & 23 & 3 & 1 & 990 \\
Extremadura & 48 & 19 & 30 & 2 & 2 & 599 \\
Castile-La Mancha & 46 & 27 & 22 & 3 & 2 & 972 \\
Rioja & 40 & 26 & 30 & 1 & 3 & 597 \\
Castile-Leon & 37 & 21 & 34 & 4 & 4 & 799 \\
Madrid & 36 & 40 & 18 & 3 & 3 & 796 \\
\hline Source: CIS 2891-2904 studies. Only data from the 13 slow-track regions available.
\end{tabular}


Table 3 The impact of regional and national considerations on the probability of voting for the regional government or the opposition

\begin{tabular}{|c|c|c|c|c|c|}
\hline & $\begin{array}{c}\text { Model } \\
1 \\
\end{array}$ & $\begin{array}{c}\text { Model } \\
2 \\
\end{array}$ & $\begin{array}{c}\text { Model } \\
3 \\
\end{array}$ & $\begin{array}{c}\text { Model } \\
4 \\
\end{array}$ & $\begin{array}{c}\text { Model } \\
5 \\
\end{array}$ \\
\hline \multicolumn{6}{|l|}{ Attitudes towards the incumbent party } \\
\hline Party proximity $(0-1)$ & $\begin{array}{c}6.632 * * * \\
(0.801)\end{array}$ & $\begin{array}{c}5.511 * * * \\
(0.788)\end{array}$ & $\begin{array}{c}4.982 * * * \\
(0.699)\end{array}$ & $\begin{array}{c}4.720 * * * \\
(0.735)\end{array}$ & $\begin{array}{c}4.389 * * * \\
(0.831)\end{array}$ \\
\hline Ideological distance $(0-1)$ & $\begin{array}{c}-3.095 * * * \\
(0.691)\end{array}$ & $\begin{array}{c}-2.893 * * * \\
(0.748)\end{array}$ & $\begin{array}{c}-2.487 * * * \\
(0.667)\end{array}$ & $\begin{array}{c}-2.439 * * * \\
(0.684)\end{array}$ & $\begin{array}{c}-1.996^{* *} \\
(0.719)\end{array}$ \\
\hline \multicolumn{6}{|l|}{ Governments } \\
\hline PSOE government (other) & & $\begin{array}{c}-1.608^{* * *} \\
(0.285)\end{array}$ & $\begin{array}{c}-1.590^{* * *} \\
(0.319)\end{array}$ & $\begin{array}{c}-1.830^{* * *} \\
(0.331)\end{array}$ & $\begin{array}{c}-0.530 \\
(0.492)\end{array}$ \\
\hline Regional government evaluation $(0-1)$ & & $\begin{array}{c}3.100 * * * \\
(0.229)\end{array}$ & & $\begin{array}{c}2.212 * * * \\
(0.264)\end{array}$ & $\begin{array}{c}1.852 * * * \\
(0.262)\end{array}$ \\
\hline National government evaluation $(0-1)$ & & $\begin{array}{c}-2.082 * * * \\
(0.350)\end{array}$ & & $\begin{array}{l}-0.882 \dagger \\
(0.463)\end{array}$ & $\begin{array}{c}-0.705 * \\
(0.346)\end{array}$ \\
\hline National government eval. X PSOE gov & ernment & $\begin{array}{c}3.378 * * * \\
(0.451)\end{array}$ & & $\begin{array}{c}1.907 * * \\
(0.581)\end{array}$ & $\begin{array}{l}1.015^{*} \\
(0.453)\end{array}$ \\
\hline \multicolumn{6}{|l|}{ Leaders } \\
\hline Regional president evaluation $(0-1)$ & & & $\begin{array}{c}3.251 * * * \\
(0.639)\end{array}$ & $\begin{array}{c}2.473 * * * \\
(0.643)\end{array}$ & $\begin{array}{c}3.289 * * * \\
(0.662)\end{array}$ \\
\hline National Prime Minister evaluation $(0-1$ & & & $\begin{array}{c}-2.522 * * * \\
(0.478)\end{array}$ & $\begin{array}{c}-2.216^{* * *} \\
(0.518)\end{array}$ & $\begin{array}{c}-0.760 \\
(0.487)\end{array}$ \\
\hline National PM evaluation X PSOE govern & ment & & $\begin{array}{c}3.608 * * * \\
(0.565)\end{array}$ & $\begin{array}{c}2.579 * * * \\
(0.589)\end{array}$ & $\begin{array}{l}0.947 \dagger \\
(0.532)\end{array}$ \\
\hline Regional opposition leader eval. (0-1) & & & & & $\begin{array}{c}-3.121 * * * \\
(0.677)\end{array}$ \\
\hline Constant & $\begin{array}{c}-2.941 * * * \\
(0.318)\end{array}$ & $\begin{array}{c}-3.042 * * * \\
(0.490)\end{array}$ & $\begin{array}{c}-3.015^{* * *} \\
(0.535)\end{array}$ & $\begin{array}{c}-3.410^{* * *} \\
(0.504)\end{array}$ & $\begin{array}{c}-2.855 * * * \\
(0.510)\end{array}$ \\
\hline Pseudo $\mathrm{R}^{2}$ (McFadden) & 0.45 & 0.50 & 0.51 & 0.53 & 0.55 \\
\hline Number of clusters & 17 & 17 & 17 & 17 & 17 \\
\hline $\mathrm{N}$ & 10,488 & 10,323 & 10,000 & 9,865 & 8,430 \\
\hline
\end{tabular}


Table 4 The impact of national and regional considerations on voting with same and different incumbents at the regional and the national level

\begin{tabular}{|c|c|c|}
\hline & Model 1 & Model 2 \\
\hline Party proximity $(0-1)$ & $\begin{array}{c}5.382^{* * * *} \\
(0.904)\end{array}$ & $\begin{array}{c}4.120 * * * \\
(1.117)\end{array}$ \\
\hline Ideological distance $(0-1)$ & $\begin{array}{c}-2.609 * * \\
(0.916)\end{array}$ & $\begin{array}{c}-1.754 \dagger \\
(0.923)\end{array}$ \\
\hline Regional opposition leader evaluation $(0-1)$ & $\begin{array}{c}-2.583 * * * \\
(0.544)\end{array}$ & $\begin{array}{c}-3.021 * * * \\
(0.753)\end{array}$ \\
\hline PSOE government (PP) & $\begin{array}{l}-0.308 \\
(0.478)\end{array}$ & $\begin{array}{c}2.754 * * \\
(0.953)\end{array}$ \\
\hline PSOE government X Regional government eval. (0-1) & $\begin{array}{c}-1.715^{* *} \\
(0.554)\end{array}$ & \\
\hline National government eval. (0-1) & $\begin{array}{c}-1.454 * * * \\
(0.382)\end{array}$ & \\
\hline PSOE gvt. X National government eval. (0-1) & $\begin{array}{c}2.334 * * * \\
(0.488)\end{array}$ & \\
\hline Regional government evaluation $(0-1)$ & $\begin{array}{c}4.183 * * * \\
(0.292)\end{array}$ & \\
\hline Regional president assess. (0-1) & & $\begin{array}{c}6.776^{* * *} \\
(0.751)\end{array}$ \\
\hline PSOE gvt. X Regional president eval. (0-1) & & $\begin{array}{c}-4.212 * * * \\
(0.846)\end{array}$ \\
\hline National PM eval. (0-1) & & $\begin{array}{c}-1.908^{*} \\
(0.791)\end{array}$ \\
\hline PSOE gvt. X National PM eval. & & $\begin{array}{c}3.277 * * * \\
(0.907)\end{array}$ \\
\hline National opposition leader eval. $(0-1)$ & & $\begin{array}{l}2.758^{*} \\
(1.250)\end{array}$ \\
\hline PSOE gvt. X National opposition leader eval. & & $\begin{array}{c}-4.039^{*} \\
(1.705)\end{array}$ \\
\hline Constant & $\begin{array}{c}-2.512 * * * \\
(0.432)\end{array}$ & $\begin{array}{c}-4.795 * * * \\
(0.471)\end{array}$ \\
\hline Pseudo $\mathrm{R}^{2}$ (McFadden) & 0.52 & 0.57 \\
\hline Number of clusters & 13 & 13 \\
\hline $\mathrm{N}$ & 6,874 & 6,768 \\
\hline
\end{tabular}

*** $\mathrm{p}<0.001, * * \mathrm{p}<0.01, * \mathrm{p}<0.05, \dagger \mathrm{p}<0.1$. All variables are dummies or have been recoded to range from 0 to 1 . Entries are logistic regression coefficients. Standard errors clustered by region are within the parentheses. Only those 13 regions either governed by the PSOE or the PP are included. The variable 'PSOE government' is a dummy 'which takes value ' 1 ' when the interviewee lives in a region governed by the PSOE, and ' 0 ' when lives in a region governed by the PP. 
Table 5 The effect of regional and national governments' evaluation on voting by national identity

\begin{tabular}{|c|c|c|c|c|}
\hline & \multicolumn{2}{|c|}{ Model 1} & \multicolumn{2}{|c|}{ Model 2} \\
\hline & $\begin{array}{l}\text { More attached } \\
\text { to Spain }\end{array}$ & $\begin{array}{l}\text { More attached } \\
\text { to their region }\end{array}$ & $\begin{array}{c}\text { All } \\
\text { regions }\end{array}$ & $\begin{array}{c}\text { Slow-track } \\
\text { regions }\end{array}$ \\
\hline Party proximity $(0-1)$ & $6.684^{* * * *}$ & $4.175^{* * * *}$ & $5.391 * * *$ & $5.442 * * *$ \\
\hline & $(0.431)$ & $(0.725)$ & $(0.751)$ & $(0.529)$ \\
\hline Ideological distance $(0-1)$ & $\begin{array}{c}-2.068^{* *} \\
(0.724)\end{array}$ & $\begin{array}{c}-2.088^{* *} \\
(0.694)\end{array}$ & $\begin{array}{c}-2.449^{* *} \\
(0.772)\end{array}$ & $\begin{array}{c}-4.181 * * * \\
(0.726)\end{array}$ \\
\hline Regional opposition leader evaluation (0-1) & $\begin{array}{c}-3.720^{* * *} \\
(0.507)\end{array}$ & $\begin{array}{c}-2.959^{* *} \\
(0.965)\end{array}$ & $\begin{array}{c}-2.699^{* * *} \\
(0.540)\end{array}$ & $\begin{array}{c}-2.498 * * * \\
(0.649)\end{array}$ \\
\hline Regional government eval. (0-1) & $\begin{array}{c}3.020 * * * \\
(0.431)\end{array}$ & $\begin{array}{c}3.268^{* * * *} \\
(0.446)\end{array}$ & $\begin{array}{c}3.156^{* * * *} \\
(0.388)\end{array}$ & $\begin{array}{c}3.002 * * * \\
(0.447)\end{array}$ \\
\hline National government eval. $(0-1)$ & $\begin{array}{c}-1.569^{* *} \\
(0.598)\end{array}$ & $\begin{array}{c}0.831 \\
(0.534)\end{array}$ & $\begin{array}{c}-2.326^{* * * *} \\
(0.653)\end{array}$ & $\begin{array}{c}-1.954^{*} \\
(0.820)\end{array}$ \\
\hline PSOE regional government (no) & $\begin{array}{c}-1.245^{* *} \\
(0.434)\end{array}$ & $\begin{array}{c}0.391 \\
(0.487)\end{array}$ & $\begin{array}{c}-2.196^{* * *} \\
(0.296)\end{array}$ & $\begin{array}{c}-2.778 * * * \\
(0.476)\end{array}$ \\
\hline National gvt. eval. X PSOE regional gvt. & $\begin{array}{c}2.845^{* * * *} \\
(0.796)\end{array}$ & $\begin{array}{l}-0.153 \\
(0.637)\end{array}$ & $\begin{array}{c}4.460^{* * * *} \\
(0.735)\end{array}$ & $\begin{array}{c}5.326^{* * * *} \\
(1.258)\end{array}$ \\
\hline National identity $(0-1)$ & & & $\begin{array}{l}-0.817 \\
(0.620)\end{array}$ & $\begin{array}{l}-1.737 \dagger \\
(0.987)\end{array}$ \\
\hline Regional gvt. eval. X National identity & & & $\begin{array}{l}-0.068 \\
(0.967)\end{array}$ & $\begin{array}{c}1.674 \\
(1.639)\end{array}$ \\
\hline National gvt. eval. X National identity & & & $\begin{array}{l}2.114 \dagger \\
(1.164)\end{array}$ & $\begin{array}{c}1.446 \\
(1.788)\end{array}$ \\
\hline PSOE gvt. X National identity & & & $\begin{array}{c}2.811 * * * \\
(0.544)\end{array}$ & $\begin{array}{c}3.547 * * * \\
(0.801)\end{array}$ \\
\hline PSOE gvt. X National gvt. eval. X National id. & & & $\begin{array}{c}-4.638 * * * \\
(1.194)\end{array}$ & $\begin{array}{c}-6.735^{* * *} \\
(1.982)\end{array}$ \\
\hline Constant & $\begin{array}{c}-2.636 * * * \\
(0.500)\end{array}$ & $\begin{array}{c}-2.445 * * * \\
(0.517)\end{array}$ & $\begin{array}{c}-1.929 * * \\
(0.696)\end{array}$ & $\begin{array}{c}-1.602 * * * \\
(0.376)\end{array}$ \\
\hline Pseudo $\mathrm{R}^{2}$ (McFadden) & 0.606 & 0.404 & 0.525 & 0.617 \\
\hline Number of clusters & 17 & 17 & 17 & 13 \\
\hline $\mathrm{N}$ & 1,355 & 2,315 & 8,405 & 3,816 \\
\hline
\end{tabular}

*** $\mathrm{p}<0.001,{ }^{* *} \mathrm{p}<0.01,{ }^{*} \mathrm{p}<0.05, \dagger \mathrm{p}<0.1$. All variables are dummies or have been recoded to range from 0 to 1 . Entries are logistic regression coefficients. Standard errors clustered by the 17 regions are within the parentheses. Both models include an interaction term between the party in regional office and the national government evaluation, in order to model the conditional relationship between these two factors. 
Table 6 Political sophistication and the impact of regional and national considerations on voting

\begin{tabular}{|c|c|c|}
\hline & $\begin{array}{l}\text { Regional vs. National } \\
\text { governments }\end{array}$ & $\begin{array}{c}\text { Regional vs. National } \\
\text { presidents }\end{array}$ \\
\hline Party proximity $(0-1)$ & $\begin{array}{c}5.312 * * * \\
(0.742)\end{array}$ & $\begin{array}{c}4.540 * * * \\
(0.797)\end{array}$ \\
\hline Ideological distance $(0-1)$ & $\begin{array}{c}-2.472 * * \\
(0.763)\end{array}$ & $\begin{array}{c}-2.048 * * \\
(0.743)\end{array}$ \\
\hline Education $(0-1)$ & $\begin{array}{l}-1.943^{*} \\
(0.830)\end{array}$ & $\begin{array}{c}-2.024 * * \\
(0.663)\end{array}$ \\
\hline PSOE government (no) & $\begin{array}{c}-2.043 * * \\
(0.649)\end{array}$ & $\begin{array}{c}-2.051 * * \\
(0.635)\end{array}$ \\
\hline Regional government evaluation $(0-1)$ & $\begin{array}{c}1.926 * * * \\
(0.436)\end{array}$ & \\
\hline Regional government evaluation X Education & $\begin{array}{l}2.144^{*} \\
(0.938)\end{array}$ & \\
\hline National government evaluation $(0-1)$ & $\begin{array}{l}-1.641 \dagger \\
(0.859)\end{array}$ & \\
\hline National government evaluation X Education & $\begin{array}{c}0.334 \\
(1.014)\end{array}$ & \\
\hline PSOE gvt. X National gvt. eval. & $\begin{array}{c}4.088 * * * \\
(1.035)\end{array}$ & \\
\hline PSOE gvt. X National gvt. eval. X Education & $\begin{array}{c}-3.409 * \\
(1.375)\end{array}$ & \\
\hline PSOE gvt. X Education & $\begin{array}{l}2.123^{* *} \\
(0.646)\end{array}$ & $\begin{array}{c}2.789 * * * \\
(0.662)\end{array}$ \\
\hline Regional opposition leader eval. (0-1) & $\begin{array}{c}-0.264 * * * \\
(0.044)\end{array}$ & $\begin{array}{c}-0.343 * * * \\
(0.069)\end{array}$ \\
\hline Regional president evaluation $(0-1)$ & & $\begin{array}{c}3.146 * * * \\
(0.698)\end{array}$ \\
\hline Regional president evaluation X Education & & $\begin{array}{l}1.597 \dagger \\
(0.916)\end{array}$ \\
\hline National Prime Minister evaluation (0-1) & & $\begin{array}{l}-1.961 * \\
(0.975)\end{array}$ \\
\hline National PM evaluation X Education & & $\begin{array}{l}1.714 \dagger \\
(0.987)\end{array}$ \\
\hline PSOE government X National PM evaluation & & $\begin{array}{c}4.190 * * * \\
(0.987)\end{array}$ \\
\hline PSOE government X National PM evaluation $Y$ & ucation & $\begin{array}{c}-4.753 * * * \\
(1.078)\end{array}$ \\
\hline Constant & $\begin{array}{l}-1.087 \\
(0.844)\end{array}$ & $\begin{array}{l}-1.218^{*} \\
(0.574)\end{array}$ \\
\hline Pseudo R ${ }^{2}$ (McFadden) & 0.525 & 0.544 \\
\hline Number of clusters & 17 & 17 \\
\hline $\mathrm{N}$ & 8,565 & 8,497 \\
\hline
\end{tabular}


Figure 1 Marginal effects of the regional president and government performance assessment on voting under situations of divided and united government

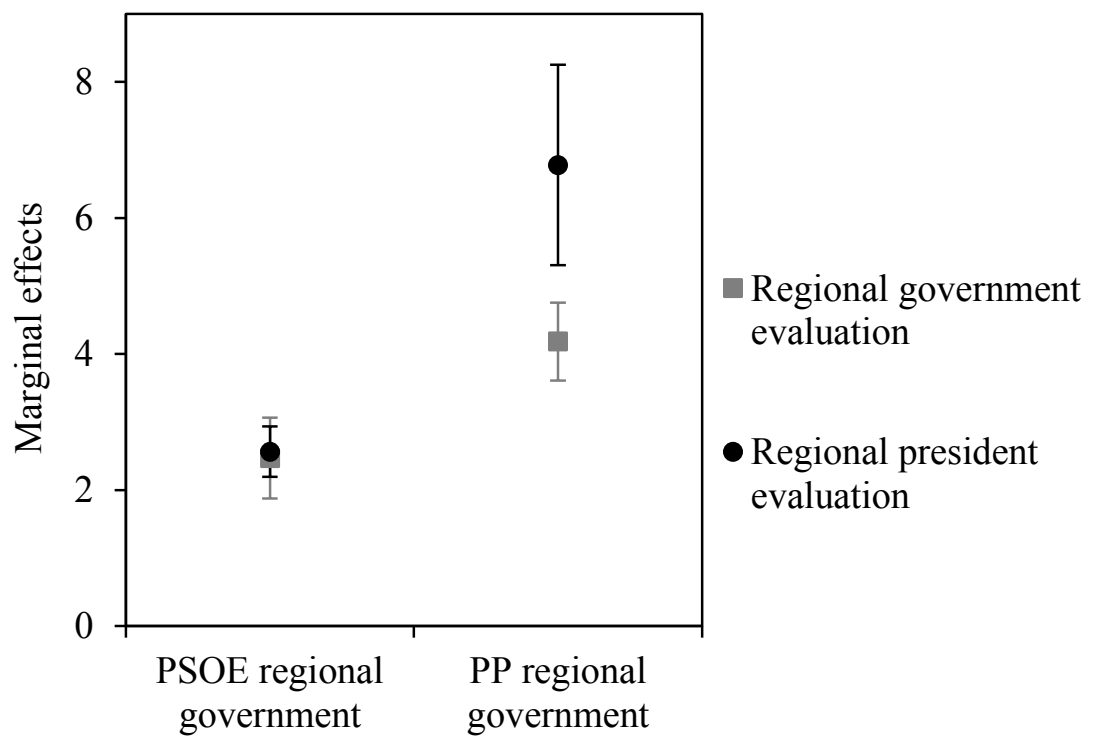


Figure 2 The conditional effect of national identity and the evaluation of national government on regional voting
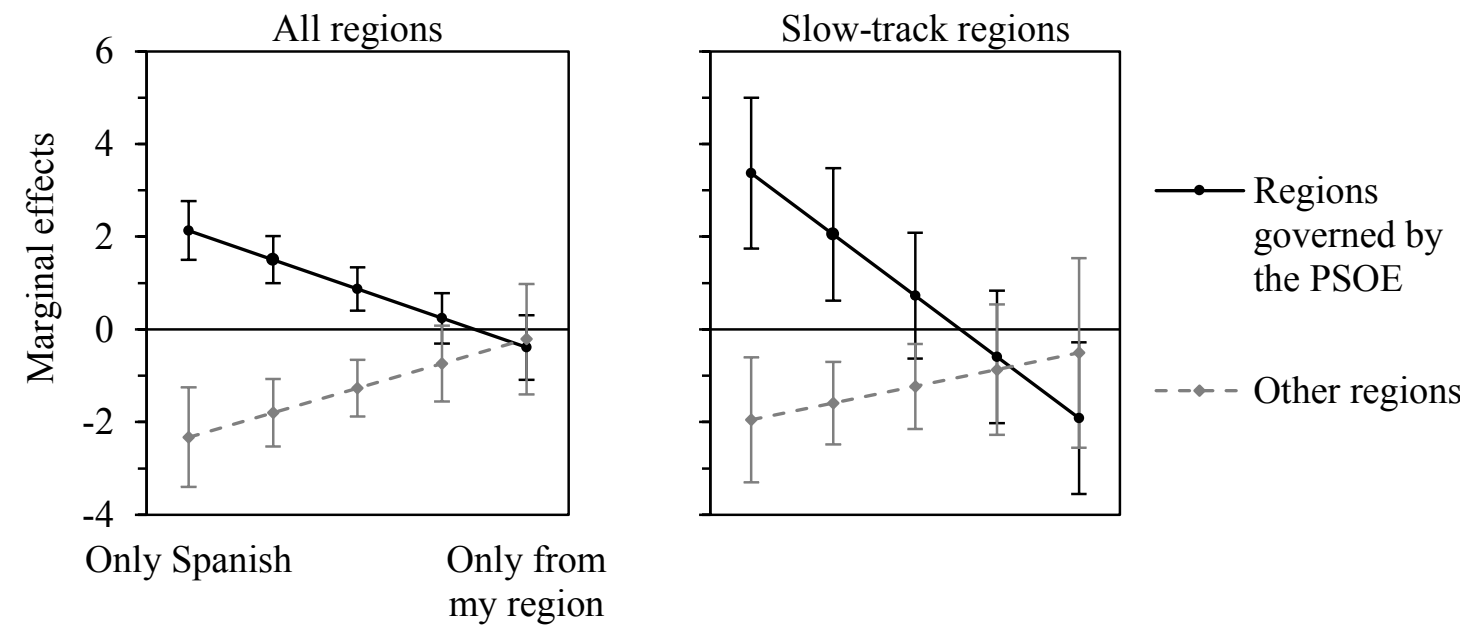
Figure 3 The conditional effect of education and regional and national governments' evaluation on regional voting
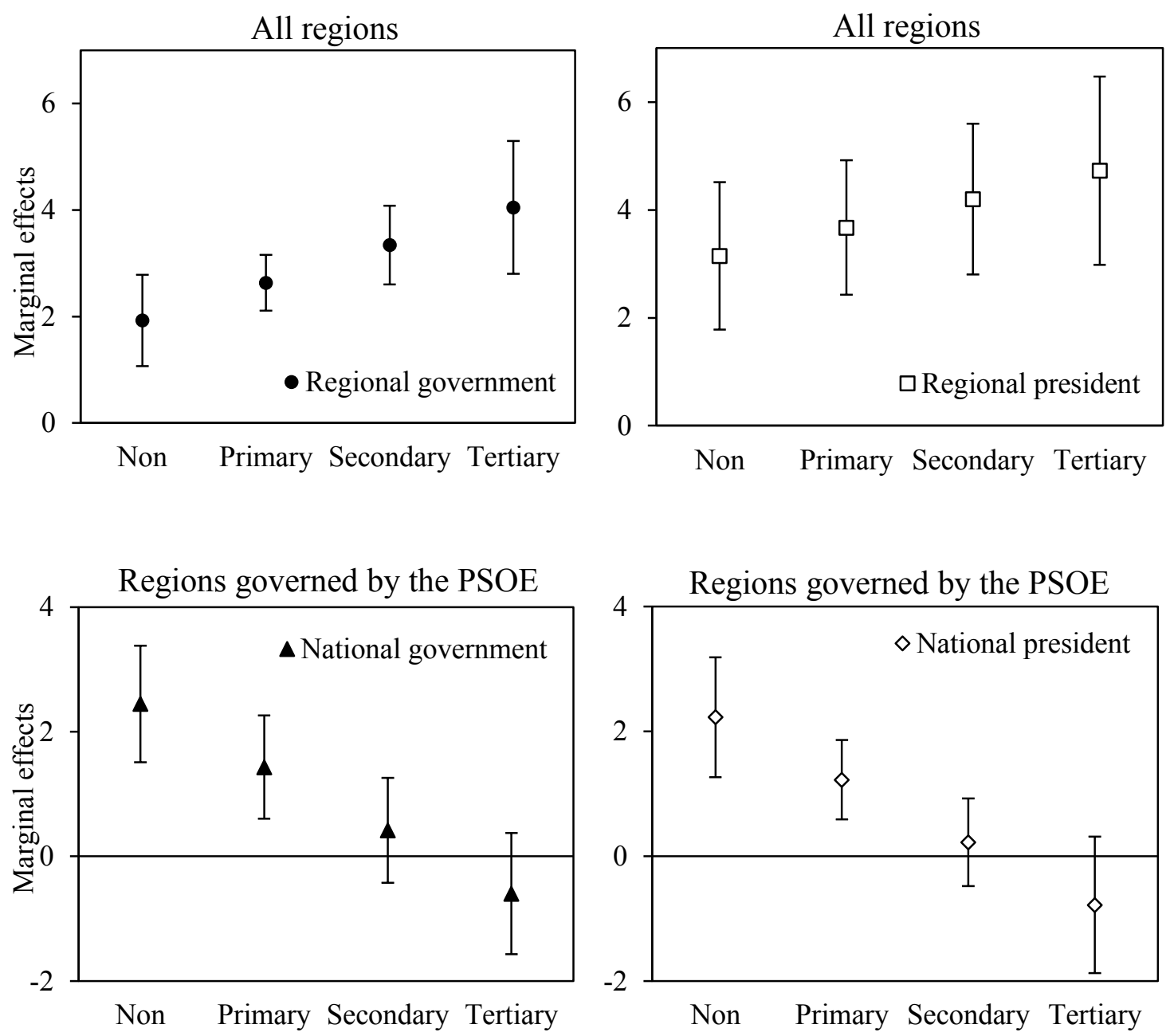


\section{References}

Aja, Eliseo. 2003. El Estado autonómico: federalismo y hechos diferenciales. $2^{\mathrm{a}}$ ed. Madrid: Alianza.

Alesina, Alberto, and Howard Rosenthal. 1996. "A Theory of Divided Government." Econometrica 64(6): 1311-41.

Anderson, Christopher J. 1995. Blaming the Government: Citizens and the Economy in Five European Democracies. New York: M.E. Sharpe.

Anderson, Christopher J. 2000. "Economic Voting and Political Context: A Comparative Perspective." Electoral Studies 19(2-3): 151-70.

Anderson, Christopher J. 2006. "Economic Voting and Multilevel Governance: A Comparative Individual-Level Analysis.” American Journal of Political Science 50(2): 449-63.

_. 2008. "Economic Voting, Multilevel Governance and Information in Canada." Canadian Journal of Political Science 41(2): 329-54.

Anderson, Christopher J., Silvia M. Mendes, and Yuliya V. Tverdova. 2004. "Endogenous Economic Voting: Evidence from the 1997 British Election.” Electoral Studies 23(4): 683708.

Arceneaux, Kevin. 2006. "The Federal Face of Voting: Are Elected Officials Held Accountable for the Functions Relevant to Their Office?" Political Psychology 27(5): 731-54.

Atkeson, Lonna Rae, and Randall W. Partin. 1995. "Economic and Referendum Voting: A Comparison of Gubernatorial and Senatorial Elections." American Political Science Review 89(1): 99-107.

Balfour, Sebastian, and Alejandro Quiroga. 2007. The Reinvention of Spain: Nation and Identity since Democracy. Oxford: Oxford University Press.

Barreiro, Belén, and Ignacio Sánchez-Cuenca. 2012. "In the Whirlwind of the Economic Crisis: Local and Regional Elections in Spain, May 2011." South European Society and Politics 17(2): 1-14.

Bartels, Larry M. 1996. "Uninformed Votes: Information Effects in Presidential Elections." American Journal of Political Science 40(1): 194-230.

— 2002. "Beyond the Running Tally: Partisan Bias in Political Perceptions." Political Behavior 24(2): 117-50.

Bartle, John. 2005. "Homogeneous Models and Heterogeneous Voters." Political Studies 53(4): 653-75. 
Brown, Adam R. 2010. "Are Governors Responsible for the State Economy? Partisanship, Blame, and Divided Federalism." The Journal of Politics 72(3): 605-15.

Campbell, Angus. 1960. "Surge and Decline: A Study of Electoral Change." Public Opinion Quarterly 24(3): 397-418.

Colomer, Josep Maria. 1998. “The Spanish 'State of Autonomies': Non-Institutional Federalism.” West European Politics 21(4): 40-52.

Converse, Philip E. 1964. "The Nature of Belief Systems in Mass Publics." In Ideology and Discontent, ed. David E. Apter. New York: The Free Press of Glencoe, 206-61.

. 1975. "Public Opinion and Voting Behaviour." In Handbook of Political Science, Volume 4: Nongovernmental Politics, eds. Fred I. Greenstein and Nelson W. Polsby. Reading, Mass.: Addison-Wesley, 75-169.

Curtice, John. 2001. "Is Devolution Succouring Nationalism?” Contemporary Wales 14(1): 80103.

Curtice, John, and Michael Steed. 2000. “Appendix: An Analysis of the Result.” In British Politics and European Elections 1999, eds. David Butler and Martin Westlake. London: Macmillan, 240-56.

Cutler, Fred. 2004. "Government Responsibility and Electoral Accountability in Federations." Publius: The Journal of Federalism 34(2): 19-38.

—. 2008. "One Voter, Two-First Order Elections?” Electoral Studies 27(3): 492-503.

Dandoy, Regis, and Arjan H. Schakel, eds. 2013. Regional and National Elections in Western Europe. Territoriality of the Vote in Thirteen Countries. Basingstoke/Houndmills: Palgrave Macmillan.

Delli Carpini, Michael X., and Scott Keeter. 1996. What Americans Know About Politics and Why It Matters. New Haven: Yale University Press.

Denver, David, and Robert Johns. 2010. “Scottish Parliament Elections: 'British Not Scottish' or 'More Scottish than British'?" Scottish Affairs 70: 1-20.

Duch, Raymond M., and Harvey D. Palmer. 2002. "Heterogeneous Perceptions of Economic Conditions in Cross-National Perspective.” In Economic Voting, eds. Han Dorussen and Michael Taylor. London: Routledge, 139-72.

Duch, Raymond M., Harvey D. Palmer, and Christopher J. Anderson. 2000. "Heterogeneity in Perceptions of National Economic Conditions." American Journal of Political Science 44(4): 635-52.

van der Eijk, Cees, and Mark N. Franklin. 1996. Choosing Europe? The European Electorate and National Politics in the Face of the Union. Ann Arbor: University of Michigan Press. 
Evans, Geoffrey, and Robert Andersen. 2006. "The Political Conditioning of Economic Perceptions." The Journal of Politics 68(1): 194-207.

Evans, Geoffrey, and Mark Pickup. 2010. "Reversing the Causal Arrow: The Political Conditioning of Economic Perceptions in the 2000-2004 U.S. Presidential Election Cycle." The Journal of Politics 72(04): 1236-51.

Fiorina, Morris P. 1983. "Who Is Held Responsible? Further Evidence on the Hibbing-Alford Thesis." American Journal of Political Science 27(1): 158-64.

Fournier, Patrick. 2002. "The Uninformed Canadian Voter." In Citizen Politics: Research and Theory in Canadian Political Behaviour, eds. Joanna Everitt and Brenda O'Neill. Don Mills: Oxford University Press, 92-109.

Franklin, Mark, Michael Marsh, and Christopher Wlezien. 1994. "Attitudes toward Europe and Referendum Votes: A Response to Siune and Svensson.” Electoral Studies 13(2): 117-21.

Franklin, Mark N. 2002. "Learning from the Danish Case: A Comment on Palle Svensson's Critique of the Franklin Thesis." European Journal of Political Research 41(6): 751-57.

Golder, Matt. 2006. "Presidential Coattails and Legislative Fragmentation." American Journal of Political Science 50(1): 34-48.

Hibbing, John R., and John R. Alford. 1981. "The Electoral Impact of Economic Conditions: Who Is Held Responsible?” American Journal of Political Science 25(3): 423-39.

Hobolt, Sara B., and James Tilley. 2014. Blaming Europe? Responsibility Without Accountability in the European Union. Oxford: Oxford University Press.

Hooghe, Liesbet, Gary Marks, and Arjan H. Schakel. 2010. The Rise of Regional Authority: A Comparative Study of 42 Democracies. Abingdon: Routledge.

Hough, Dan, and Charlie Jeffery. 2006. Devolution and Electoral Politics. Manchester: Manchester University Press.

Jacobson, Gary C. 1991. "Explaining Divided Government: Why Can't the Republicans Win the House?" PS: Political Science and Politics 24(4): 640-43.

Jeffery, Charlie, and Dan Hough. 2003. "Regional Elections in Multi-Level Systems." European Urban and Regional Studies 10(3): 199-212.

Johns, Robert. 2011. "Credit Where It's Due? Valence Politics, Attributions of Responsibility, and Multi-Level Elections." Political Behavior 33(1): 53-77.

Johns, Robert, James Mitchell, David Denver, and Charles Pattie. 2009. "Valence Politics in Scotland: Towards an Explanation of the 2007 Election." Political Studies 57(1): 207-33. 
Jones, Richard Wyn, and Roger Scully. 2006. "Devolution and Electoral Politics in Scotland and Wales." Publius: The Journal of Federalism 36(1): 115-34.

Koch, Jeffrey W. 2000. "Candidate Status, Presidential Approval, and Voting for US Senator." Electoral Studies 19(4): 479-92.

Lago-Peñas, Ignacio, and Santiago Lago-Peñas. 2010. "Decentralization and Electoral Accountability." Environment and Planning C: Government and Policy 28(2): 318-34.

León, Sandra. 2011. "Who Is Responsible for What? Clarity of Responsibilities in Multilevel States: The Case of Spain.” European Journal of Political Research 50(1): 80-109.

—. 2012. "How Do Citizens Attribute Responsibility in Multilevel States? Learning, Biases and Asymmetric Federalism. Evidence from Spain.” Electoral Studies 31(1): 120-30.

Lewis-Beck, Michael S. 2006. "Does Economics Still Matter? Econometrics and the Vote." Journal of Politics 68(1): 208-12.

Liñeira, Robert. 2011. "'Less at Stake' or a Different Game? Regional Elections in Catalonia and Scotland.” Regional \& Federal Studies 21(3): 283-303.

—. 2014. El Estado de las autonomías en la opinión pública: preferencias, conocimiento y voto. Madrid: Centro de Investigaciones Sociológicas.

Linz, Juan J. 1973. "Early State-Building and Late Peripheral Nationalism against the State: The Case of Spain." In Building States and Nations. Volume 2, eds. Samuel N. Eisenstadt and Stein Rokkan. London: Sage, 32-116.

Luskin, Robert C. 1990. "Explaining Political Sophistication.” Political Behavior 12(4): 331-61.

Manin, Bernard, Adam Przeworski, and Susan C. Stokes. 1999. "Elections and Representation." In Democracy, Accountability, and Representation, eds. Adam Przeworski, Susan C. Stokes, and Bernard Manin. Cambridge: Cambridge University Press, 29-54.

Neuman, W. Russell. 1986. The Paradox of Mass Politics: Knowledge and Opinion in the American Electorate. Cambridge: Harvard University Press.

Pallarés, Francesc, and Michael Keating. 2003. "Multi-Level Electoral Competition: Regional Elections and Party Systems in Spain.” European Urban and Regional Studies 10(3): 23955.

Pallarés, Francesc, José Ramón Montero, and Francisco José Llera. 1997. "Non State-Wide Parties in Spain: An Attitudinal Study of Nationalism and Regionalism." Publius: The Journal of Federalism 27(47): 135-70.

Petrocik, John R., and Joseph Doherty. 1996. "The Road to Divided Government: Paved without Intention." In Divided Government: Change, Uncertainty, and the Constitutional Order, ed. Peter F. Galderisi. New York: Rowman \& Littlefield, 85-107. 
Popkin, Samuel L. 1994. The Reasoning Voter: Communication and Persuasion in Presidential Campaigns. 2nd ed. Chicago: University of Chicago Press.

Powell, G. Bingham. 2000. Elections as Instruments of Democracy: Majoritarian and Proportional Visions. New Haven: Yale University Press.

Powell, G. Bingham, and Guy D. Whitten. 1993. "A Cross-National Analysis of Economic Voting: Taking Account of the Political Context." American Journal of Political Science 37(2): 391-414.

Rahn, Wendy M., Jon A. Krosnick, and Marijke Breuning. 1994. "Rationalization and Derivation Processes in Survey Studies of Political Candidate Evaluation." American Journal of Political Science 38(3): 582-600.

Reif, Karlheinz, and Hermann Schmitt. 1980. "Nine Second-Order Elections: A Conceptual Framework for the Analysis of European Election Results." European Journal of Political Research 9: 3-44.

Remmer, Karen L., and François Gélineau. 2003. "Subnational Electoral Choice Economic and Referendum Voting in Argentina, 1983-1999." Comparative Political Studies 36(7): 80121.

Riba, Clara. 2000. "Voto Dual Y Abstención Diferencial: Un Estudio Sobre El Comportamiento Electoral En Cataluña.” Revista Española de Investigaciones Sociológicas 91: 59-88.

Riba, Clara, and Aida Díaz. 2002. "Economic Voting in Subnational Government. Catalonian Evidence." In Economic Voting, eds. Han Dorussen and Michaell Taylor. London: Routledge, 173-99.

Riera, Pedro. 2013. "Voting Differently across Electoral Arenas: Empirical Implications from a Decentralized Democracy.” International Political Science Review 34(5): 561-81.

Rivers, Douglas. 1988. "Heterogeneity in Models of Electoral Choice." American Journal of Political Science 32(3): 737-57.

Rodden, Jonathan. 2004. "Comparative Federalism and Decentralization: On Meaning and Measurement." Comparative Politics 36(4): 481-500.

Rudolph, Thomas J. 2003a. "Institutional Context and the Assignment of Political Responsibility." Journal of Politics 65(1): 190-215.

- 2003b. "Who's Responsible for the Economy? The Formation and Consequences of Responsibility Attributions." American Journal of Political Science 47(4): 698-713.

_. 2006. "Triangulating Political Responsibility: The Motivated Formation of Responsibility Judgments." Political Psychology 27(1): 99-122. 
Sanders, David, and Sean Carey. 2002. "Temporal Variations in Economic Voting: A Comparative Cross-National Analysis." In Economic Voting, eds. Han Dorussen and Michael Taylor. London: Routledge, 200-232.

Schakel, Arjan H. 2013. "Congruence Between Regional and National Elections." Comparative Political Studies 46(5): 631-62.

Shafer, Byron E., and William J. M. Claggett. 1995. The Two Majorities: The Issue Context of Modern American Politics. Baltimore: The Johns Hopkins University Press.

Siune, Karen, Palle Svensson, and Ole Tonsgaard. 1994. "The European Union: The Danes Said 'no' in 1992 but 'yes' in 1995: How and Why?' Electoral Studies 13(2): 107-16.

Sniderman, Paul M., Richard A. Brody, and Philip Tetlock. 1991. Reasoning and Choice: Explorations in Political Psychology. Cambridge: Cambridge University Press.

Snyder, Richard. 2001. "Scaling down: The Subnational Comparative Method." Studies in Comparative International Development 36(1): 93-110.

Soroka, Stuart N., and Christopher Wlezien. 2004. "Opinion Representation and Policy Feedback: Canada in Comparative Perspective." Canadian Journal of Political Science/Revue canadienne de science politique 37(03): 531-59.

- 2010. 35 Degrees of Democracy. Politics, Public Opinion, and Policy. Cambridge: Cambridge University Press.

Stein, Robert M. 1990. "Economic Voting for Governor and U.S. Senator: The Electoral Consequences of Federalism." The Journal of Politics 52(01): 29-53.

Tilley, James, and Sara B. Hobolt. 2011. "Is the Government to Blame? An Experimental Test of How Partisanship Shapes Perceptions of Performance and Responsibility." The Journal of Politics 73(2): 316-30.

Wilson, Timothy D., Dana S. Dunn, Dolores Kraft, and Douglas J. Lisle. 1989. "Introspection, Attitude Change, and Attitude-Behavior Consistency: The Disruptive Effects of Explaining Why We Feel the Way We Do." In Advances in Experimental Social Psychology, ed. Leonard Berkowitz. New York: Academic Press, 287-343.

Wlezien, Christopher, Mark N. Franklin, and Daniel Twiggs. 1997. "Economic Perceptions and Vote Choice: Disentangling the Endogeneity." Political Behavior 19(1): 7-17.

Zaller, John R. 1991. "Information, Values, and Opinion.” American Political Science Review 85(4): 1215-37. 1992. The Nature and Origins of Mass Opinion. Cambridge: Cambridge University Press. 
${ }^{1}$ This reasoning is already present in the early studies of the US congressional elections. According to Campbell (1960), the main difference between the presidential and the congressional elections is the quantity of stimulus offered to the public: the lower the stimulus, the less intense the campaign and the media coverage of the vote. In consequence, public's interest and knowledge are lower in low-stimulus elections, resulting in lower turnout and lower relevance of election-specific factors on vote choice.

${ }^{2}$ The second-order model was inspired by the 1979 founding elections to the European parliament (Reif and Schmitt 1980). The peculiar nature of this vote - in which national party systems are used to elect an international parliament which does not select a government - made of these elections the quintessential second-order vote. It is also been argued that issues related to the European Union tend to be low-salient, rarely affecting voters' choices even in EUrelated votes, although this is the subject of some debate (Franklin, Marsh, and Wlezien 1994; Franklin 2002; Siune, Svensson, and Tonsgaard 1994).

${ }^{3}$ Although there is broad consensus that the main electoral consequence of federalism is to harm accountability (Anderson 2006; Powell and Whitten 1993), it has also been argued that federalism debilitates government responsiveness and representation because it confuses the signal citizens receive about the policies introduced by the different governments (Soroka and Wlezien 2004, 2010).

${ }^{4}$ Although this is not an original strategy, it departs our study from the main contributions on voting in regional elections, based on the analysis of electoral outcomes (Dandoy and Schakel 2013; Hough and Jeffery 2006; Schakel 2013). Previous studies already used the voter as unit of analysis (Cutler 2008; Johns 2011; Riba and Díaz 2002), but they usually focused on one or two regions.

${ }^{5}$ We refer by out-party governments to those contexts where the regional incumbent party is different than the national one, and by in-party governments to those where the incumbent party is the same at both the regional and the national level.

${ }^{6}$ Since the mid-90s all regions are in charge of policy areas such as education and health services. The main asymmetry is not related to policy responsibilities but at the level of revenue powers: the special fiscal arrangements in the Basque Country and Navarra makes the financing of these two regions different from the other fifteen (Aja 2003; León 2012). 
${ }^{7}$ The 13 slow-track regions also hold their elections concurrently with the Spanish local elections, which are celebrated on the same day nationwide. This creates additional opportunities to nationalize the regional elections further.

${ }^{8}$ The quantity and relevance of NSWPs constitutes the most peculiar characteristic of the Spanish party system(s). This is usually interpreted as both a cause and a consequence of the establishment of regional elections in Spain. In some regions, the electoral success of NSWPs points primarily to the shortcomings of the Spanish state-wide parties as instruments of political integration (Pallarés, Montero, and Llera 1997), difficulties that arise from deficits in the Spanish nation-building process (Balfour and Quiroga 2007; Linz 1973). In other regions, the existence of NSWPs stems from the simultaneous processes of decentralization and party system institutionalization. Although some NSWPs got national representation out of the so-called historical regions of Catalonia, Basque Country, and Galicia, the phenomenon was fueled by the collapse of the UCD in October 1982 general elections. The collapse led former UCD representatives to build new regionalist parties for the May 1983 founding regional elections in the slow-track regions (Pallarés, Montero, and Llera 1997).

${ }^{9}$ All NSWPs benefit from dual voting at regional elections, which constitutes a stable pattern of voting change from state-wide parties to nationalist parties at regional elections. Dual voting has been a prevalent phenomenon in Catalonia (Liñeira 2011; Riba 2000; Riera 2013), and, to a lesser extent, in Aragón, Cantabria, or Galicia (Pallarés and Keating 2003).

${ }^{10}$ Some reward-punishment voting models include non-voters assuming that abstention may constitute a punishment to the incumbent. However, we exclude abstainers from our dependent variable because supporting the opposition is different than non-voting and, especially, because it is difficult to assume that the latter constitutes a punishment for the incumbent in the low-turnout context that characterizes regional elections.

${ }^{11}$ By endogenous relationship we mean the possibility that retrospective evaluations are just a consequence and not a cause of the vote, a prospect that would produce an overestimation of the effect of the former on the latter. This is a possibility that can never be ruled out when using observational data (Evans and Andersen 2006; Wlezien, Franklin, and Twiggs 1997). Endogeneity constitutes a serious challenge to causal inferences, but we believe that our conclusions are not seriously challenged by endogeneity problems because our main interest does not lie in the effect of evaluations on the vote, but on conditional relationships, i.e., how the impact of evaluations varies across contexts and types of voters. 
${ }^{12}$ The fact that some regional opposition leaders are not very well-known among voters results in the loss of some observations.

${ }^{13}$ The ideological distance is measured according to the following formula: Ideological distance $=\mid$ voter selfreported position in the left-right dimension - voter position of the government's party |.

${ }^{14}$ The surveys were conducted by the Centro de Investigaciones Sociológicas (CIS), a public institute that represents the most significant survey research center in Spain. The surveys used are studies number 2750 (Andalucia, March 2008 elections); 2795-2796 (Basque Country and Galicia, March 2009 elections); 2891-2904 (slow-track regions, May 2011 elections); and 2857 (Catalonia, November 2010). All data may be downloaded from http://www.cis.es/. ${ }^{15}$ According to Johns, 'an economic crisis is liable to render most non-national elections more second-order, because voters will be preoccupied by an issue for which national governments are principally responsible' (Johns 2011, 55). In fact, the PSOE lost all five regional governments where the socialists were the incumbent party, anticipating its electoral defeat in the 2011 general elections. A chronicle of the 2011 regional and local elections can be found in Barreiro \& Sánchez-Cuenca (2012).

${ }^{16}$ The inclusion in our analysis of regions governed by parties without national links would overestimate the impact of regional considerations; by contrast, focusing on regions governed by parties with national and regional branches constitutes a fairer test of hypothesis 1 . The exclusion of regions governed by NSWPs implies that the Canary Islands, Cantabria, Navarre and the Basque Country - which had the Canarian Coalition, the Regionalist Party of Cantabria, the Navarrese People's Union, and the Basque Nationalist Party as incumbents before the 2008-2011 elections - are excluded from the analysis contained in Table 4.

${ }^{17}$ Apart from their presence in regional party manifestos and regional election campaigns, voters are also used to rationalizing their regional ballot choices in terms of regional interests. Asked about why they voted the way they did it and offering respondents different options, an average of 23 per cent of those who voted in our thirteen slowtrack regions answered 'because it's the party that best stands up for the interests of my region'. This is the second most common answer of the seven offered ('it's the party that best represents my ideas' is the most common, with 26 per cent). It is important to note that the regional rationalization is clearly the most common answer in a substantial number of slow-track regions, which points to the importance of this kind of reasoning among the Spanish electorate. 